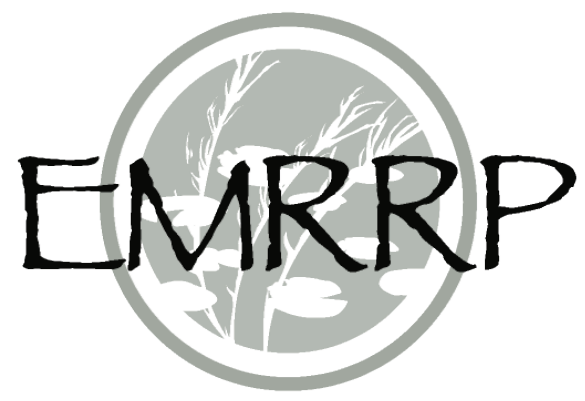

\title{
Developing Conceptual Models for Assessing Benefits and Impacts of USACE Activities on Freshwater Mussel Communities
}

by Brook Herman, Todd Slack, and Todd Swannack

PURPOSE: In this report, we describe how aspects of existing freshwater mussel indices of biological integrity can be modified to fit within the planning paradigm established for developing and certifying ecological models for U.S. Army Corps of Engineers' planning purposes. Herein, we present examples of using freshwater mussels for biological monitoring, how to calculate their associated IBIs specific to their region of origin and their potential use in ecosystem restoration planning. Additionally, we present general conceptual models that may be used in ecological model development and environmental benefits analysis for projects that focus on freshwater mussel habitat restoration.

BACKGROUND: Although worldwide in distribution, freshwater mussels in North America have the greatest diversity, with nearly 300 recognized taxa (Williams et al. 1993). Aquatic biodiversity, including freshwater mussels, is considerably higher within the American Southeast relative to other comparable regions (Lydeard and Mayden 1995). Unfortunately, freshwater mussels are one of the groups of species being most quickly identified as conservation targets, with over $43 \%$ of extant North American species already listed as endangered (Haag 2012). This decline has been attributed to damming (impoundments and inundation of riffle habitat) in major river systems, loss of obligate fish hosts, and increases in industrial and domestic pollution (Bogan 1993; Watters 1996), as well as increased eutrophication of aquatic systems (Wilcove et al. 1998) and rates of siltation (Brim-Box and Mossa 1999; Waters 1995). Downing, Meter, and Woolnough (2010) noted in their review of impacts on mussel communities that habitat destruction, alteration, or both was the most frequently cited cause for declining populations.

In suitable habitat, freshwater mussels rarely occur as monospecific groupings, occurring instead as multispecies communities (Strayer 2008). The spatial and temporal distribution of these communities is influenced by physical characteristics, such as channel morphology, stream flow, near-bed turbulence, water quality, sediment dynamics, and land use within the watershed. In general, mussel populations require flowing water, stable channels, and good water quality. Mussels are filter feeders, consuming planktonic algae and other organisms from the water column. Most species exhibit a complex life cycle, requiring an intermediate fish host for successful transition from the larval to the adult life history stage (Figure 1). The biphasic life cycle consists of a parasitic larva and sessile adult (Barnhart, Haag, and Roston 2008) with the larval form functioning as parasites (termed glochidia) on external features (for example, gills, fins) of various fish species. Some species of mussels are generalists and can use multiple fish species as their glochidial hosts, while others require specific species for host selection. The density of host species 
can affect the spatial distribution of mussels. This limitation on distribution can be particularly problematic from a natural resource perspective because the glochidia cannot successfully metamorphose into adult mussels if the correct species of fish is not present (Haag and Warren 1998).

Because of mussels' sessile nature and relative period of longevity, "freshwater mussels are excellent indicators of water quality and habitat stability" (Watters 2000, as cited by Reed 2014). In addition, mussels provide important ecosystem services through filtration of suspended particulates (Vaughn and Hakenkamp 2001; Vaughn, Nichols, and Spooner 2008; Vaughn 2010; Howard and Cuffey 2006). These attributes render mussel communities very suitable as biomonitoring tools and restoration targets (Grabarkiewicz and Davis 2008). Unfortunately, the restoration of freshwater mussel populations in the past has been hampered by a lack of quantitative information regarding species-habitat interactions. The complex relationship between the physical and biological factors makes it difficult to predict how mussels will be distributed within a channel or watershed. Recently, however, advances in our understanding of habitat and mussel life history requirements, along with similar advances in computer technology and geospatial resources, have fostered the development of greater predictive power for modeling mussel occurrences (Smit and Kaeser 2016; Walters et al. 2017).

One of the mission areas of the US Army Corps of Engineers (USACE) is ecosystem restoration, specifically aquatic resources. USACE has successfully carried out many river and stream restoration projects (for example, Upper Mississippi River Environmental Management, Hoffman Dam Removal, Kissimmee River Restoration). Because of the increasingly rare status, restoration of freshwater mussel communities has become a focus for many USACE restoration projects. To justify investing federal dollars into an ecosystem restoration project, the environmental benefits of the proposed restoration measures must be quantified. Thus, USACE must use a model, or models, that appropriately captures the ecological response resulting from a proposed restoration action. Life history complexity and habitat specificity make prediction of spatial distribution and mussel species assemblages difficult. Predicting environmental benefits of a suite of species, such as freshwater mussels, necessitates the use of a community model or index. Index-based models are useful tools that can simplify ecosystem complexity by focusing on the limiting factors required for species viability. Previous research on developing index-driven models for mussels used the index of biological integrity (IBI) developmental methodology, also called index of biotic integrity. In this report, we describe how aspects of existing mussel IBIs can be modified to fit within the paradigm established for ecological models developed for USACE ecosystem restoration activities. Herein, we present select case examples using freshwater mussels for biological monitoring and their potential use in ecosystem restoration planning. Additionally, we present general conceptual models that may be used in model development and environmental benefits analysis for mussels.

\section{DEVELOPMENT OF COMMUNITY BASED INDICES FOR ASSESSING BIOLOGICAL}

INTEGRITY: Growing concerns over declining environmental conditions, especially water resources, were the subject of much debate during the 1960s and 1970s, resulting in the passage of numerous federal regulations in an effort to curb continuing declines in the quality of water resources (Karr et al. 1986; Karr 1991). This effort drove the development of an effective means to monitor and assess current impacts on these resources, as well a means to gauge improvements 
(Courtemanch, Davies, and Laverty 1989). Initial monitoring efforts frequently relied solely on chemical and physical water-quality measurements, which were often critiqued because of the lack of integration of biological responses (Karr 1987; Miller et al. 1988).

Karr (1981) developed the IBI as a relatively rapid and inexpensive bioassessment protocol using metrics related to species composition (for example, richness, number of tolerant species) and ecological attributes of the community (for example, proportion omnivores, proportion with disease or anomalies). Karr championed the use of fishes primarily because of the familiarity of the group among regional resource managers, but also because species represent a variety of trophic levels, extensive life history information is available, and the group is easily relatable to the public. In addition, various aquatic communities have been used as environmental indicators to measure watershed condition (Berkman, Rabeni, and Boyle 1986; Hilsenoff 1977; Resh and Unzicker 1975); however, there is a long tradition of using fishes (Fausch et al. 1990; Simon 1998; Simon and Lyons 1995) and, to a lesser extent, macroinvertebrates (Kerans and Karr 1994; Black and MacCoy 1999), as the focus of freshwater IBIs.

The traditional approach (Davis and Simon 1995; Barbour et al. 1999) to developing a communitybased multi-metric index is to first define the area of concern (for example, first-order streams of Ohio) and then identify a list of probable metrics to be tested (for example, species richness). The next step is to analyze the sensitivity and correlation of metrics to a variety of environmental variables (for example, host fish abundance) with a multiyear data collection effort in a variety of areas that represent a gradient of human disturbance within the area of concern. Testing should reveal which metrics are most sensitive to human activities and whether any metrics are highly covariable. The index is then calibrated to reflect the specific level of human alteration within the model domain (for example, a gradient from reference area to highest level of alteration). Once all of the metrics are chosen and evaluated, indices are integrated into an overall index of habitat quality. There are several different integration techniques used for combining the indices, but the most common are arithmetic or geometric means. Finally, the index is tested in habitats previously unsampled to ensure the efficacy of the model within a chosen level of confidence.

Alternatively, the use of multivariate statistics can be used to identify appropriate metrics and calibrate metric scores using a specific community (for example, fish abundance per sample site) and environmental parameters (for example, turbidity, dissolved oxygen, water temperature, per sample site) (Jackson, Walker, and Poos 2010; Young et.al. 2014). Additionally, multivariate approaches can reduce investigator bias during the selection of important environmental parameters (Miranda, Aycock, and Killgore 2012). USACE-Chicago District has an ongoing effort to develop a fish (ichthyofaunal) qualitative index for the Chicago Region that is based on a priori best professional scoring of each fish species according to their level of tolerance of anthropogenic activities coupled with their habitat specificity. Fish species' scores range between 0 for extremely tolerant generalist species to 10 for extremely intolerant habitat specific species. This method is very similar to the development of the highly popular, well-studied floristic qualitative assessment index (Swink and Wilhelm 1994). Once the district reaches a consensus on the score for each fish species, a long-term (multiyear) fish collection data set will be used to calibrate the metrics and help to interpret the range of scores expected within the region. 
In general, freshwater assemblages, such as mussels, are less well understood in terms of their tolerance levels to human-induced environmental changes. Although specific tolerance levels to anthropogenic change are unknown for every species, research suggests that mussels exhibit a range of responses to various disturbances, and this sensitivity would make mussel communities good indicators of environmental condition (Strayer 2008). Overall, biological community-based indices are touted as a more encompassing measure of environmental condition than any chemical, physical, or structural measure because the biotic components of an ecosystem interact with and respond to a wide variety of chemical and physical stressors in complex ways (Cooper et al. 2018). Measuring a community-based biological response to environmental conditions can indicate environmental impacts from different types of human activities over different temporal and spatial scales.

\section{REVIEW OF MUSSEL COMMUNITY INDICES}

Case example 1. Mussel Community Index. In 2002, the Illinois Natural History Survey (INHS) developed a mussel community index (MCI) (Szafoni 2002). Although the MCI has not been formally published by its developmental team, a form of the report was published in the Ellipsaria society's newsletter (Vol 4[2]; Szafoni 2002). The INHS reports the model is working well within fourth- to fifth-order streams and rivers but has found it to have limited applicability within fast high gradient streams and large rivers (for example, Mississippi) (Szafoni 2015, personal communication). The INHS is currently recalibrating the parameters of the model to have more sensitivity to unique fluvial-geomorphologic areas. It sampled around 1000 new sites in 2009 and is working through these data with a statistician to refine scoring of the metrics.

There are four metrics, referred to as factors, in the INHS model. They include (1) number of extant species, measured as the number of live and dead species in the sample (for example, species richness), scored from 1 to 5; (2) number of extant intolerant species, measured by the number of species sensitive to human activities from the sample, scored as 1, 3, or 5; (3), catch-per-unit effort, measured as the average number of live individuals per labor hours sampling (for example, abundance), scored from 1 to 5; and (4) percentage of live species with 0-3 growth rings (for example, recent recruitment or proof of reproduction), scored from 1 to 5. Table 1 lists the MCI metrics and their scoring. The scores from each factor are added together for the MCI value. This value will range from 0 to 20. A sample that receives a MCI value of 16 or higher is considered an unique natural resource and represents the highest quality of mussel habitat within the state of Illinois. A MCI value from 0 to 4 is considered restricted. This designation means either the area is so degraded that only a few tolerant species can survive, or the area never was suitable for mussels and historically would not have had a rich mussel community regardless of human activities. Table 2 lists the categories of MCI values and how to interpret them. The scores for this IBI reflect a regionalized approach commonly used when developing index-based models - that is, the IBI includes parameters that capture the regional attributes of mussel populations (for example, total species diversity, which differs regionally, affects the range of scores for a specific metric). 


\begin{tabular}{|c|c|}
\hline Metric & Score \\
\hline 1. Extant species in sample & Species richness factor \\
\hline 0 & 1 \\
\hline $1-3$ & 2 \\
\hline $4-6$ & 3 \\
\hline $7-9$ & 4 \\
\hline $10+$ & 5 \\
\hline $\begin{array}{l}\text { 2. Number of intolerant } \\
\text { species }\end{array}$ & Intolerant species factor \\
\hline 0 & 1 \\
\hline 1 & 3 \\
\hline $2+$ & 5 \\
\hline 3. Catch-per-unit-effort & Abundance factor \\
\hline 0 & 1 \\
\hline $1-10$ & 2 \\
\hline $11-30$ & 3 \\
\hline $31-60$ & 4 \\
\hline $61+$ & 5 \\
\hline $\begin{array}{l}\text { 4. Percentage of live species } \\
\text { with recent recruitment }\end{array}$ & Reproduction factor \\
\hline 0 & 1 \\
\hline $1-30$ & 3 \\
\hline $31-50$ & 4 \\
\hline $51+$ & 5 \\
\hline
\end{tabular}

\begin{tabular}{|c||c||l||}
\hline \multicolumn{2}{||c|}{ Table 2. Categories of MCl values. } \\
\hline \hline $\mathbf{M C l}$ & $\begin{array}{c}\text { Mussel resource } \\
\text { value }\end{array}$ & Approximate description for mussel resource value \\
\hline $16+$ & Unique & $\begin{array}{l}\text { Very high species richness or abundance; listed species } \\
\text { present; evidence of recruitment common. Resource of } \\
\text { state-wide significance; EO Form required. }\end{array}$ \\
\hline $15-12$ & Highly valued & $\begin{array}{l}\text { High species richness or abundance; rare species present; } \\
\text { evidence of recent recruitment likely. Resource of state- } \\
\text { wide significance; EO Form required. }\end{array}$ \\
\hline $11-8$ & Moderate & $\begin{array}{l}\text { Species richness or abundance typical for stream of given } \\
\text { location and order. May be a resource of local significance or } \\
\text { recovering from degradation. }\end{array}$ \\
\hline $7-5$ & Limited & $\begin{array}{l}\text { Low species richness or abundance. May be recoverable or } \\
\text { recovering with improved conditions. }\end{array}$ \\
\hline $0-4$ & Restricted & $\begin{array}{l}\text { No live mussels present; only weathered dead, subfossil, or } \\
\text { no shell material found. }\end{array}$ \\
\hline \hline
\end{tabular}

Case example 2. Mussel Index of Biotic Integrity. Another academic group, from Otterbein University in Ohio, has independently developed and tested in a limited way a mussel index of biotic integrity (m-IBI) for the Big Walnut Creek in Ohio (Hoggarth and Grumney 2013, Ellenbogen 2015). They listed 10 metrics, scored as a 5, 3, or 1, and then summed the metrics for an overall 
score for the sample, ranging from 10 to 50. Table 3 lists the metrics and how they were scored. Some of the metrics are very similar to the INHS's MCI (for example, percentage of extant species). It is unclear whether the sensitivity and redundancy of these metrics have been tested.

\begin{tabular}{|l|c|c|c||}
\hline \multicolumn{3}{||}{ Mable 3. Mussel index of biotic integrity (m-IBI). } \\
\hline \hline \multicolumn{3}{|c||}{ Score } \\
\hline \hline Metric & \multicolumn{3}{|c||}{} \\
\hline Distribution and abundance & $\mathbf{3}$ & $\mathbf{1}$ \\
\hline 1. Number of state-listed species & $>10$ & $9-1$ & 0 \\
\hline 2. Percentage of state-listed species & $>30$ & $29-1$ & 0 \\
\hline 3. Number of federal-listed species & $>1$ & 1 & 0 \\
\hline & & & \\
\hline Reproductive potential & & & \\
\hline 4. Percentage of extant* species & $>60$ & $59-30$ & $<30$ \\
\hline 5. Percentage of extant individuals & $>60$ & $59-30$ & $<30$ \\
\hline 6. Ratio of mean to median age & $<0.9$ & $0.9-1.1$ & $>1.1$ \\
\hline & & & \\
\hline Community structure & & & \\
\hline 7. Shannon-Weiner Index & $>0.8$ & $0.8-0.4$ & $<0.4$ \\
\hline 8. Percentage of invasive bivalves & $<30$ & $30-76$ & $>76$ \\
\hline 9. Percentage of surface-to-burrowing species & $>70$ & $69-30$ & $<30$ \\
\hline 10. Total number of extant individuals & $>50$ & $49-30$ & $<30$ \\
\hline *living and dead & & & \\
\hline
\end{tabular}

Case example 3. Mussel Health Score. The Minnesota Department of Natural Resources (MDNR) developed a stream species quality index (SSQI) that integrates what is referred to as mussel health scores along with fish and macroinvertebrate health scores. It chose four metrics: (1) catch-per-unit effort, measured as the total live mussels per site per search time; (2) percentage of live species, measured as the count of species found live at site divided by the total count (living and dead); (3) species recruitment, measured as the count of species that had individuals in the age category of 0-5; and (4) relative tolerance, measured as the number of live individuals of tolerant species divided by the number of tolerant species. The overall score is a sum of all four metrics divided by four. This score is then integrated into the overall SSQI. It is unclear from the webbased documentation whether these metrics were tested for sensitivity and redundancy (http://www.dnr.state.mn.us/whaf/about/scores/biology/streamspc.html).

Case example 4. Mussel Community Assessment Tool. Recently, the USACE Upper Mississippi River Restoration Program Long-Term Resource Monitoring (LTRM) element initiated the development of an approach for monitoring and assessing mussel communities within the Upper Mississippi River (UMR) system. This approach, called the mussel community assessment tool (MCAT), currently consists of 10 metrics addressing a number of ecological attributes that includes information regarding conservation status and environmental sensitivity, 
taxonomic composition, population processes, and abundance and diversity (Table 4) (Dunn, Zigler, and Newton 2012; Dunn, Zigler, and Newton 2016). The MCAT is still in the development phase but has been subjected to field testing to assess variability in MCAT metrics over time, in addition to developing the criteria for establishing scoring requirements and cutoffs for specific metrics.

\begin{tabular}{|c|c|c|}
\hline Metric & Description & Ecological significance \\
\hline \multicolumn{3}{|c|}{$\begin{array}{l}\text { Conservation status / } \\
\text { sensitivity }\end{array}$} \\
\hline$\%$ listed species & $\begin{array}{l}\text { Percentage of species listed by federal or } \\
\text { state (IL, IA, MN, MO, WI) regulations as } \\
\text { endangered, threatened, or of special } \\
\text { concern }\end{array}$ & $\begin{array}{l}\text { Measure of the abundance of imperiled } \\
\text { and sensitive species }\end{array}$ \\
\hline$\%$ tolerant species & $\begin{array}{l}\text { Percentage of species classified as } \\
\text { tolerant (Amblema plicata, Quadrula } \\
\text { quadrula, and Obliquaria reflexa) } \\
\end{array}$ & $\begin{array}{l}\text { Index of species that are relatively } \\
\text { tolerant to human-induced changes to } \\
\text { habitat or water quality or both }\end{array}$ \\
\hline \multicolumn{3}{|c|}{ Taxonomic composition } \\
\hline$\%$ tribe Lampsilini & $\begin{array}{l}\text { Percentage of mussels in the tribe } \\
\text { Lampsilini }\end{array}$ & $\begin{array}{l}\text { Index of balance in taxonomic } \\
\text { composition (behavior, life history } \\
\text { characteristics) }\end{array}$ \\
\hline \multicolumn{3}{|c|}{ Population processes } \\
\hline$\%$ fresh dead & Percentage of fresh dead mussels & Index of recent mortality \\
\hline$\%$ juveniles & $\begin{array}{l}\text { Percentage of aged mussels } \leq 5 \text { years } \\
\text { old }\end{array}$ & Index of recent recruitment \\
\hline$\% \geq 15$ years old & $\begin{array}{l}\text { Percentage of aged mussels } \geq 15 \text { years } \\
\text { old }\end{array}$ & Index of balanced age distribution \\
\hline \multicolumn{3}{|l|}{ Abundance } \\
\hline $\begin{array}{l}\text { Abundance at } 75 \text { th } \\
\text { quartile }\end{array}$ & $\begin{array}{l}\text { Abundance in the quadrats at the } 3 r d \\
\text { quartile (75th percentile) }\end{array}$ & $\begin{array}{l}\text { Identifies abundance in high quality } \\
\text { areas; may identify patches or if } \\
\text { sampling occurs on the edge of a bed }\end{array}$ \\
\hline \multicolumn{3}{|l|}{ Diversity } \\
\hline Species evenness & $\begin{array}{l}\text { Pielou's evenness index (J') estimated at } \\
\text { the species level }\end{array}$ & $\begin{array}{l}\text { Estimate of the dominance of the } \\
\text { assemblage by a few species }\end{array}$ \\
\hline Tribe evenness & $\begin{array}{l}\text { Pielou's evenness index (J') estimated at } \\
\text { the tribe level }\end{array}$ & $\begin{array}{l}\text { Estimate of the dominance of the } \\
\text { assemblage by a tribe }\end{array}$ \\
\hline ES_100 & $\begin{array}{l}\text { Expected number of species at a sample } \\
\text { size of } 100 \text { mussels estimated via } \\
\text { rarefaction }\end{array}$ & $\begin{array}{l}\text { Estimate of species richness with equal } \\
\text { sample sizes }\end{array}$ \\
\hline
\end{tabular}

Case example 5. Environmental Flows Methodology. Gates, Vaugn, and Julian (2015) developed a methodology to address environmental flow needs for freshwater mussel communities in Oklahoma by encompassing information related to thermal tolerances and reproductive strategies of the sampled community. Species are characterized as either thermally sensitive or tolerant, in addition to length of brood period (short or long), primary fish-host group (for example, generalist, sunfishes, minnows, catfishes), and host infection mode (for example, free glochidia, conglutinate, mantle lure). Inclusion of the host infection mode as a guild captures the diversity of 
the reproductive strategies that have evolved to promote successful glochidia implantation, which further mirrors the ecological diversification that may exist within each respective mussel community. In addition, many of these traits tend to follow phylogenetic lines; thus, if the life history trait is unknown for a particular species, it can probably be inferred according to current phylogenetic understanding (for example, tribe Amblemini, Quadrulini). The sampled community is then partitioned into guilds according to the compiled attributes (for example, thermal tolerance, brood length, fish-host group), and additional water needs are evaluated using periods of greatest thermal stress, spawning activity, and host fish-glochidia contact. The use of functional guilds to monitor the mussel community provides a unique approach, and although initially developed to provide flow recommendations for a mussel community, aspects of this approach could be modified or integrated into other monitoring approaches for use as a bioassessment tool. For example, long-term monitoring efforts could track changes in the proportion of thermally sensitive species within the sampled community or those species that use mantle luring as means to improve reproductive success.

CONSIDERATIONS FOR DEVELOPING INDEX-BASED MODELS FOR MUSSELS: There are some trade-offs when using a mussel-based index to track changes in freshwater systems - especially if the goal is recovery of a community after a restoration action. Mussels show a strong response to current and past anthropogenic actions, but recovery can lag significantly. For example, if restoration is staged over a number of years, recovery can take anywhere from 15 to 50 years, because glochidia must come into contact with the appropriate fish species in order to colonize new areas. Fish species can show a quick response to restoration actions (for example, dam removal) because they can return to a restored area quickly. However, the timing of mussel reproduction must be in synchrony with the movement of mussel host-fish species. If the host fishes are not present during mussel spawning season, the reproductive effort will not be successful that year. Further, there is a lag between successful recruitment and detection because young mussels may take up to another five years before being large enough to be detected using current sampling protocols.

MUSSEL COMMUNITY MODEL DEVELOPMENT: Based on this review and work with subject matter experts, a simple conceptual model has been developed to illustrate the effects of water quality, hydrology, and substrate on the quality of suitable mussel habitat (Figure 2). A refinement of this general conceptual model, which focuses on one specific river system, is noted in Figure 3 and includes specific environmental needs and current stressors of the mussel community in a reach of the Meramec River in Missouri. This project area is currently slated for restoration actions by USACE-St. Louis District. The information portrayed in both conceptual models adequately illustrates that mussel communities are complex and modeling their response to future restoration actions will require parameters that encompass both life-history requirements and spatial and temporal considerations.

CONCLUSIONS: The need for restoration of freshwater mussel habitat is becoming more evident, and USACE will play a large role in its success. To efficiently move through the USACE planning process, planners and researchers will need appropriate community-based models that are easily adaptable for use in a variety of projects and locations and responsive to USACEauthorized restoration actions, meaning the models would capture change in habitat suitability as a result of proposed future restoration projects. The information provided in this technical note 
provides a good basis for the development of a general mussel community model for the USACE planning purposes. More research is needed to better understand the response of mussel communities to changes in fish movement as a result of restoration actions. For example, future efforts should investigate whether there are methods that enhance the movement of appropriate fish species to coincide with mussel reproduction to better increase mussel recruitment and establishment within newly restored areas. Research into freshwater mussels will hopefully include more empirical data collection that will further the understanding of how mussels respond to human activities, including restoration, and how to develop better management and restoration tools, such as community-based models.

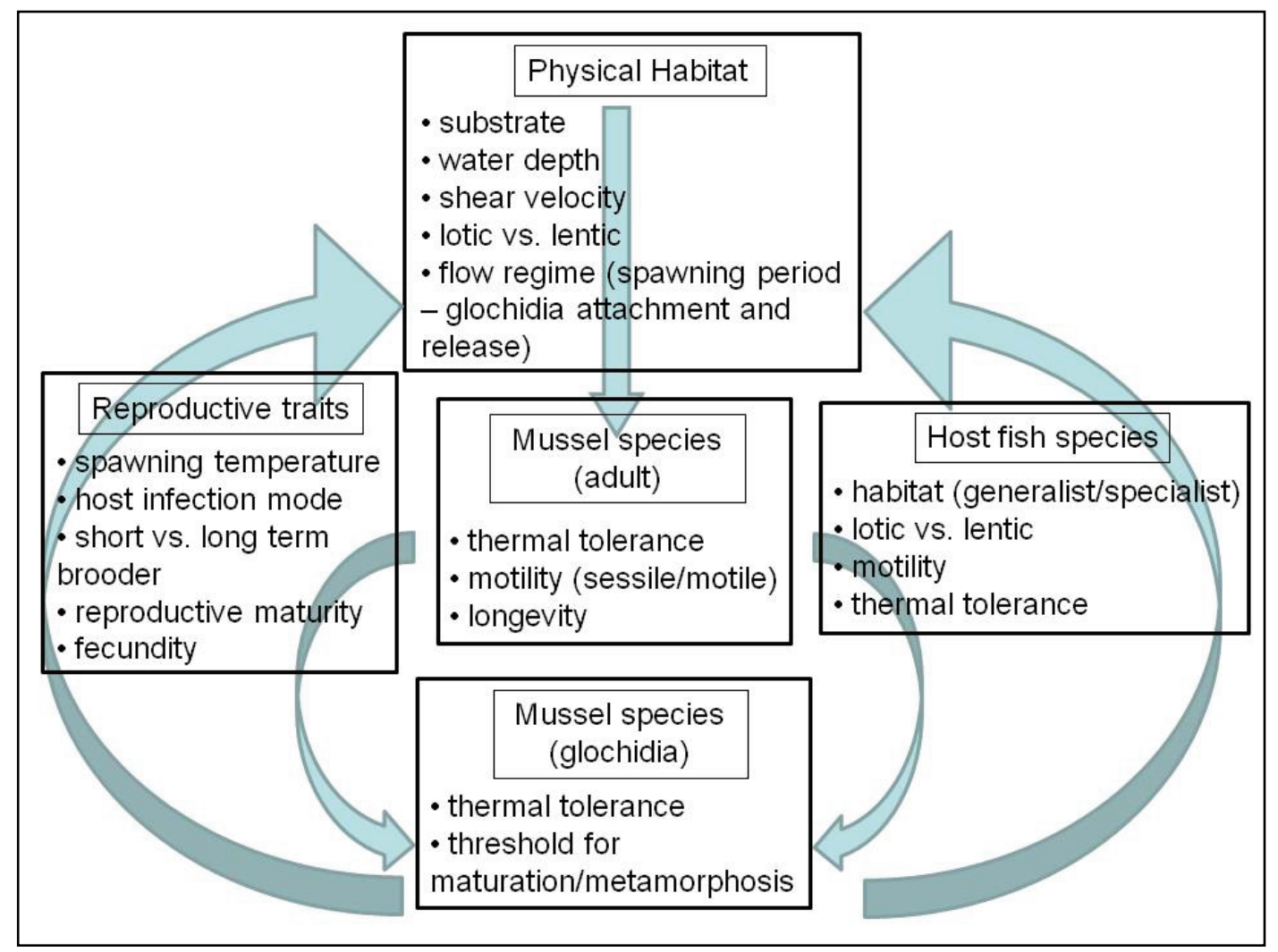

Figure 1. General overview of mussel life-history requirements, illustrating complex interaction between physical habitat, fish-host requirements, and mussel reproductive traits. (Plain text version available below.) 
ERDC/TN EMRRP-EBA-25

September 2021

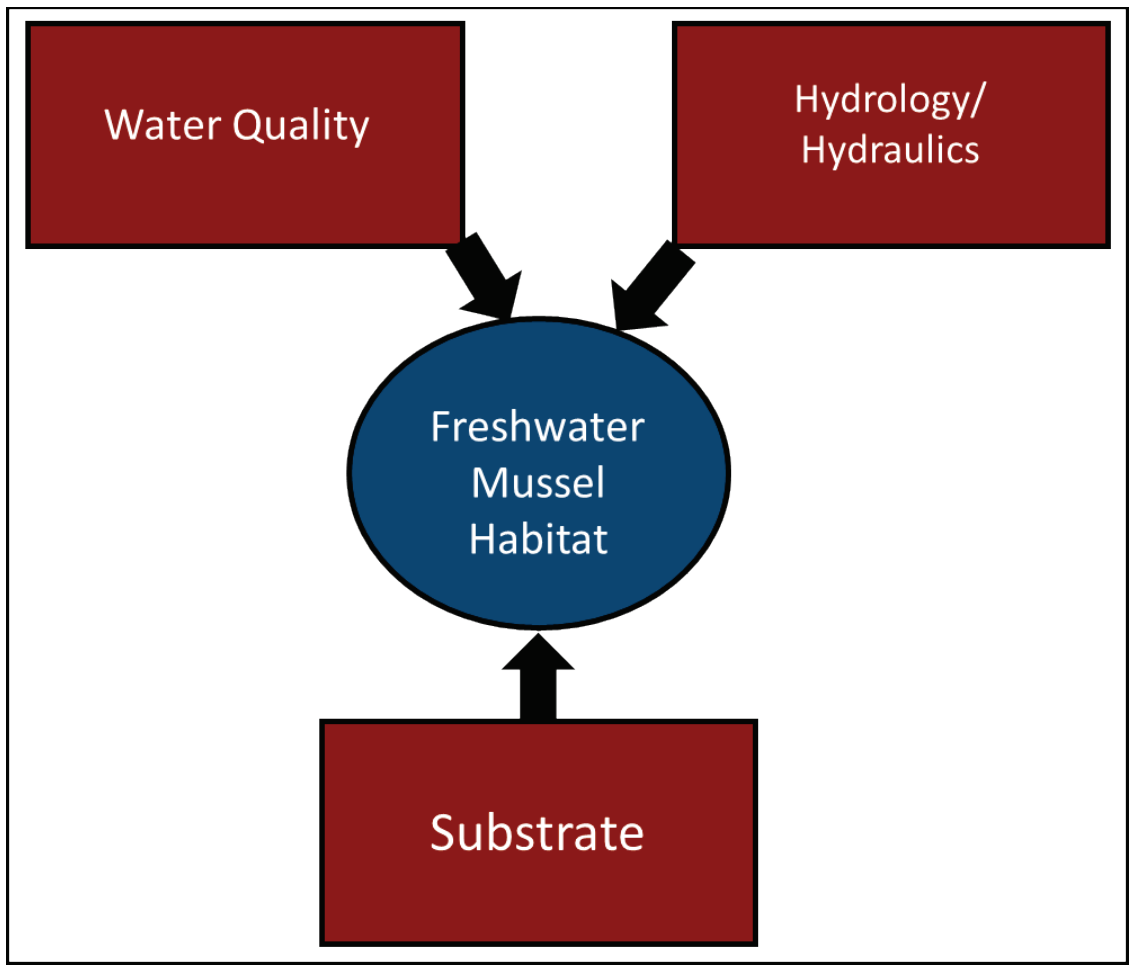

Figure 2. Conceptual model of generalized drivers for freshwater mussel habitat.

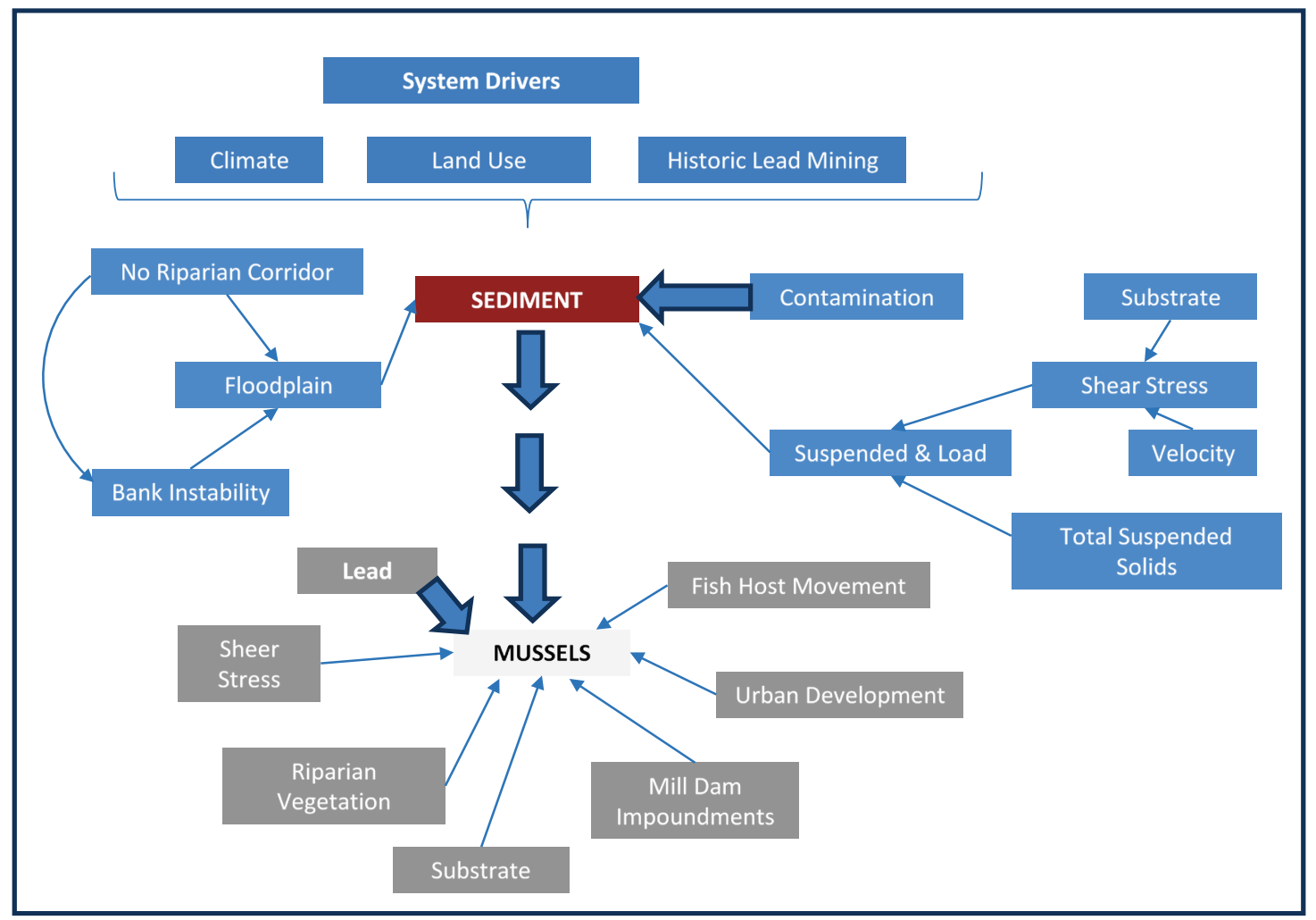

Figure 3. Conceptual model of drivers of mussel habitat in the Meramec River, Missouri. (Plain text version available below.) 


\section{BIBLIOGRAPHY}

Barbour, M. T., J. Gerritsen, B. D. Snyder, and J. B. Stribling. 1999. Rapid Bioassessment Protocols for Use in Streams and Wadeable Rivers: Periphyton, Benthic Macroinvertebrates and Fish, Second Edition. EPA 841-B-99-002. Washington, DC: US Environmental Protection Agency; Office of Water.

Barnhart, M. C., W. R. Haag, and W. N. Roston. 2008. "Adaptations to host infection and larval parasitism in Unionoida." Journal of the North American Benthological Society 27(2): 370-394.

Berkman, H. E., C. F. Rabeni, and T. P. Boyle. 1986. "Biomonitors of stream quality in agricultural areas: fish versus invertebrates." Environmental Management 10(3): 413-419.

Bogan, A. E. 1993. "Freshwater bivalve extinction (Mollusca: Unionoida): a search for causes." American Zoologist 33(6): 599-609.

Brim-Box, J., and J. Mossa. 1999. "Sediment, land use, and freshwater mussels: prospects and problems." Journal of the North American Benthological Society 18(1): 99-117.

Black, R. W., and D. E. MacCoy. 1999. The development and evaluation of a benthic index of biological integrity for the Cedar River watershed, Washington. US Geological Survey, Water-Resources Investigations Report 99-4203.

Cooper, M. J., G. A. Lamberti, A. H. Moerke, C. R. Ruetz, D. A. Wilcox, V. J. Brady, T. N. Brown, J. J. Ciborowski, G. P. Gatham, L. B. Johnson, and D. G. Uzarski. 2018. "An expanded fish-based index of biotic integrity for Great Lakes coastal wetlands." Environmental Monitoring and Assessment 190 (580). https://doi.org/10.1007/s10661-018-6950-6

Courtemanch, D. L., S. P. Davies, and E. B. Laverty. 1989. "Incorporation of biological information in water quality planning." Environmental Management 13(1): 35-41.

Davis, W. S., and T. P. Simon (eds.). 1995. Biological assessment and criteria: tools for water resource planning and decision making. Lewis Publishers, Baton Raton, FL.

Downing, J. A., P. V. Meter, and D. A. Woolnough. 2010. "Suspects and evidence: a review of the causes of extirpation and decline in freshwater mussels." Animal Biodiversity and Conservation 33(2): 151-185.

Dunn, H., S. Zigler, J. Duveyjonck, and T. Newton. 2012. "Methods to assess and monitor mussel communities in the Upper Mississippi River system.” Unpublished Technical Report to the US Army Corps of Engineers. 45 pp.

Dunn, H., S. Zigler, and T. Newton. 2016. "Validation of a mussel community assessment tool for the Upper Mississippi river system.” A completion report submitted to the US Army Corps of Engineers' Upper Mississippi River Restoration Program from the US Geological Survey, 2014MCA2. 57 pp.

Ellenbogen, J. B. 2015. Recovery potential of the mussel community in the lower section of Big Walnut Creek. Honor's Papers. Otterbein University, OH.

Fausch, K. D., J. Lyons, J. R. Karr, and P. L. Angermeier. 1990. "Fish communities as indicators of environmental degradation." American Fisheries Society Symposium 8: 123-144.

Gates, K. K., C. C. Vaugn, and J. P. Julian. 2015. "Developing environmental flow recommendations for freshwater mussels using the biological traits of species guilds." Freshwater Biology 60(4): 620-635.

Grabarkiewicz, J. D., and W. S. Davis. 2008. An introduction to freshwater mussels as biological indicators, including accounts of Interior Basin, Cumberlandian, and Atlantic Slope species. Washington, DC, US Environmental Protection Agency.

Haag, W. R. 2012. North American freshwater mussels: natural history, ecology, and conservation. Cambridge University Press. 505 p.

Haag, W. R., and J. Melvin L. Warren (1998). "Role of ecological factors and reproductive strategies in structuring freshwater mussel communities." Canadian Journal of Fisheries and Aquatic Sciences 55: 297-306.

Hilsenoff, W. L. 1977. Use of arthropods to evaluate water quality of streams. Wisconsin Department of Natural Resources Technical Bulletin 100.15 p. 
Hoggarth, M. A., and M. D. Grumney. 2013. A report on a mussel survey of Big Walnut Creek from Hoover Dam to its mouth, Franklin and Pickaway counties, $\mathrm{OH}$. Otterbein University, $\mathrm{OH}$.

Howard, J. K., and K. M. Cuffey. 2006. "The functional role of native freshwater mussels in the fluvial benthic environment." Freshwater Biology 51:460-474.

Jackson, D. A., S. C. Walker, and M. S. Poos. 2010. "Cluster analysis of fish community data: "New" tools for determining meaningful groupings of sites and species assemblages." American Fisheries Society Symposium, 73:503-527.

Karr, J. R. 1981. “Assessment of biological integrity using fish communities.” Fisheries 6:21-27.

Karr, J. R. 1987. "Biological monitoring and environmental assessment: a conceptual framework." Environmental Management 11(2):249-256.

Karr, J. R. 1991. "Biological integrity: a long-neglected aspect of water resource management." Ecological Applications 1(1): 66-84.

Karr, J. R., and E. W. Chu. 1999. Restoring life in running waters: better biological monitoring. Island Press, Covelo, CA.

Karr, J. R., K. D. Fausch, P. L. Angermeier, P. R. Yant, and I. J. Schlosser. 1986. Assessing biological integrity in running waters: a method and its rationale, Illinois Natural History Survey Special Publication 5. 28 p.

Kerans, B. L., and J. R. Karr. 1994. "A benthic index of biotic integrity (B-IBI) for rivers of the Tennessee Valley." Ecological Applications 4(4): 768-785.

Lydeard, C., and R. L. Mayden 1995. "A diverse and endangered aquatic ecosystem of the southeast United States." Conservation Biology 9(4): 800-805.

Miller, D. L., P. M. Leonard, R. M. Hughes, J. R. Karr, P. B. Moyle, L. H. Schrader, B. A. Thompson, R. A. Daniels, K. D. Fausch, G. A. Fitzhugh, J. R. Gammon, D. B. Halliwell, P. L. Angermeier, and D. J. Orth. 1988. "Regional applications of an index of biotic integrity for use in water resource management." Fisheries 13(5): 12-20.

Miranda, L. E., J. N. Aycock, and K. J. Killgore. 2012. “A Direct-Gradient Multivariate Index of Biotic Condition.” Transactions of the American Fisheries Society 141(6): 1637-1648.

Reed, M. P. 2014. "Freshwater Mussels (Bivalvia: Margaritiferidae and Unionidae) of the Buffalo River Drainage, Tennessee." Master's Thesis, University of Tennessee. https://trace.tennessee.edu/utk_gradthes/2751

Resh, V. H., and J. D. Unzicker (1975). "Water Quality Monitoring and Aquatic Organisms: The Importance of Species Identification." Water Pollution Control Federation 47(1): 9-19.

Simon, T. P. (editor). 1998. Assessing the sustainability and biological integrity of water resources using fish communities. CRC Press, Boca Raton, FL. 672 p.

Simon, T. P., and J. Lyons. 1995. Applications of the index of biotic integrity to evaluate water resource integrity in freshwater ecosystems, pp 245-262. In: W.S. Davis and T.P. Simon (Eds). Biological assessment and criteria: tools for water resource planning and decision making. Lewis Publishers, Boca Raton, FL. 415 p.

Smit, R., and A. Kaeser. 2016. "Defining freshwater mussel mesohabitat associations in an alluvial, Coastal Plain river." Freshwater Science 35(4):1276-1290.

Strayer, D. L. 2008. Freshwater mussel ecology: a multifactor approach to distribution and abundance. Freshwater Ecology Series, V 1. The University of California, $204 \mathrm{p}$.

Swink, F., and G. Wilhelm. 1994. Plants of the Chicago Region. $4^{\text {th }}$ Ed. The Morton Arboretum, Lisle, IL.

Szafoni, R. E. 2002. Freshwater mussel classification index. In Illinois natural areas inventory - approved standards and guidelines. pp. 66-71.

Szafoni, R. E. 2015. Personal Communication.

Vaughn, C. C. 2010. "Biodiversity losses and ecosystem function in freshwaters: emerging conclusions and research directions." BioScience 60(1):25-35. 
Vaughn, C. C., and C. C. Hakenkamp. 2001. "The functional role of burrowing bivalves in freshwater ecosystems." Freshwater Biology 46:1431-1446.

Vaughn, C. C., S. J. Nichols, and D. E. Spooner. 2008. "Community and foodweb ecology of freshwater mussels." Journal of the North American Benthological Society 27(2): 409-423.

Walters, A. D., D. Ford, E. T. Chong, M. G. Williams, N. B. Ford, L. R. Williams, and J. A. Banta. 2017. Highresolution ecological niche modelling of threatened freshwater mussels in east Texas, USA. Aquatic Conservation: Marine and Freshwater Ecosystems: 1-10.

Waters, T. F. 1995. Sediments in streams: sources, biological effects and control. American Fisheries Society Monograph 7. American Fisheries Society, Bethesda, Maryland, USA. 251 p.

Watters, G. T. 1996. "Small dams as barriers to freshwater mussels (Bivalvia Unionoida) and their hosts." Biological Conservation 75(1):79-85.

Watters, G. T. 2000. Freshwater mussels and water quality: A review of the effects of hydrologic and instream habitat alterations. Pages 261-274 In: R.A. Tankersely, R.A., D.R. Warmolts, G.T. Watters, B.J. Armitage, P.D. Johnson, and R.S. Butler, editors. Freshwater Mollusk Symposia Proceedings. Ohio Biological Survey, Columbus, Ohio.

Wilcove, D. S., D. Rothstein, J. Dubow, A. Phillips, and E. Losos. 1998. "Quantifying Threats to Imperiled Species in the United States: Assessing the relative importance of habitat destruction, alien species, pollution, overexploitation, and disease." BioScience 48(8): 607-615.

Williams, J. D., M. L. Warren, Jr., K. S. Cummings, J. L. Harris, and R. J. Neves. 1993. "Conservation status of freshwater mussels of the United States and Canada." Fisheries 18(9): 6-22.

Young, S., H. Yang, D. Huang, S. Liu, Y. Huang, C. Chiang, and J. Liu. 2014. "Using benthic macroinvertebrate and fish communities as bioindicators of the Tanshui River Basin around the Great Taipei area - multivariate analysis of spatial variation related to levels of water pollution." Environmental Research and Public Health 11:71167143.

NOTE: The contents of this technical note are not to be used for advertising, publication, or promotional purposes. Citation of trade names does not constitute an official endorsement or approval of the use of such products. 